
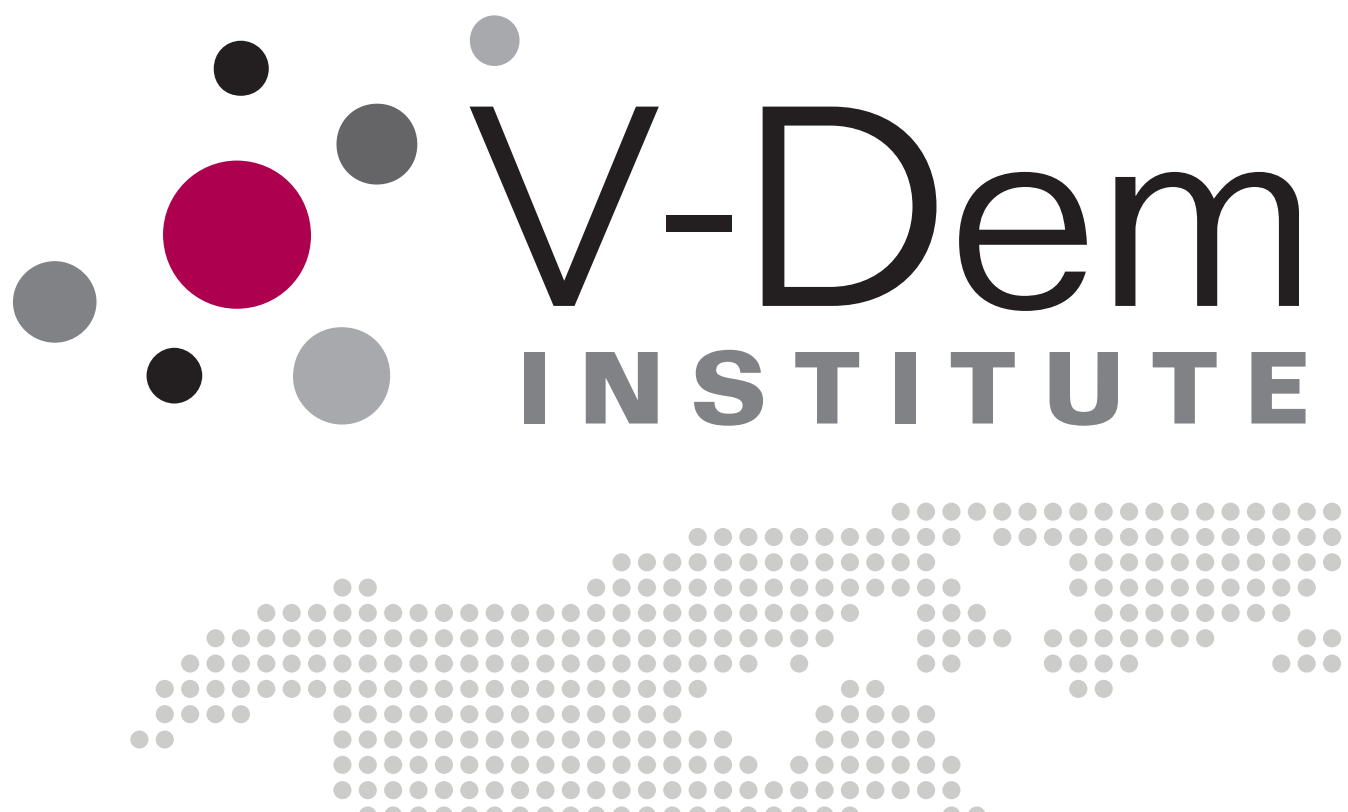

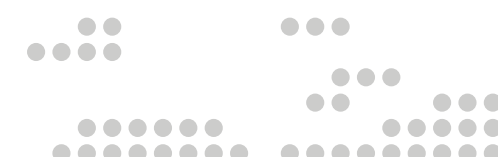

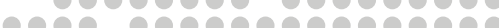
00000000000000000

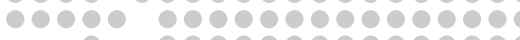
1.0 0000

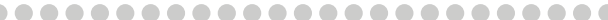

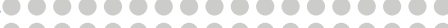

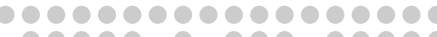

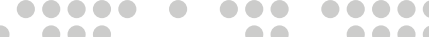
1000000000000008

Democracy and Corruption: A Global Time-Series Analysis with V-Dem Data

Kelly M. McMann, Brigitte Seim, Jan Teorell, and Staffan I. Lindberg

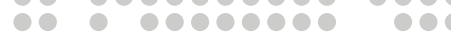

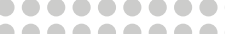

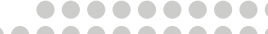
10000000000000000 1000000000000000

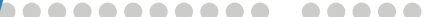

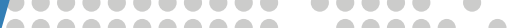

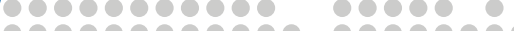

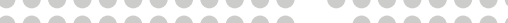

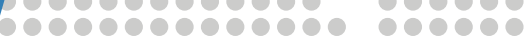

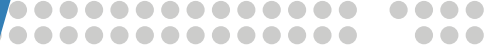

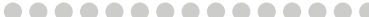

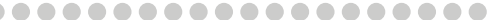
10000000000000090000

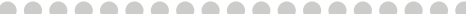

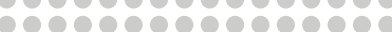

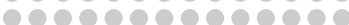

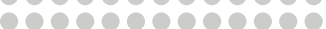

10000000000

00000000000

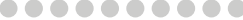

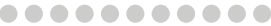

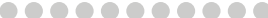
00000000000

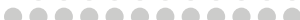
robrobró

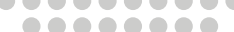

60898980 0000000

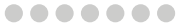

000000

0000000

000000

000000

1000

6re8e

OP

100000

100

100

10

10

90

P

March 2017

\section{Working Paper}

SERIES 2017:43

THE VARIETIES OF DEMOCRACY INSTITUTE 
Varieties of Democracy (V-Dem) is a new approach to the conceptualization and measurement of democracy. It is co-hosted by the University of Gothenburg and University of Notre Dame. With a V-Dem Institute at University of Gothenburg that comprises almost ten staff members, and a project team across the world with four Principal Investigators, fifteen Project Managers, 30+ Regional Managers, 170 Country Coordinators, Research Assistants, and 2,500 Country Experts, the V-Dem project is one of the largest-ever social science researchoriented data collection programs.

Please address comments and/or queries for information to:

V-Dem Institute

Department of Political Science

University of Gothenburg

Sprängkullsgatan 19, PO Box 711

SE 40530 Gothenburg

Sweden

E-mail: contact@v-dem.net

V-Dem Working Papers are available in electronic format at www.v-dem.net.

Copyright (C) 2017 by authors. All rights reserved. 


\title{
Democracy and Corruption: \\ A Global Time-Series Analysis with V-Dem Data ${ }^{1}$
}

\author{
Kelly M. McMann \\ Associate Professor of Political Science \\ Case Western University \\ Brigitte Seim \\ Assistant Professor of Public Policy \\ University of North Carolina, Chapel Hill \\ Jan Teorell \\ Professor of Political Science \\ Lund University \\ Staffan I. Lindberg \\ Professor of Political Science \\ Director, V-Dem Institute \\ University of Gothenburg
}

\begin{abstract}
1 We are grateful to Lucas Flowers, Mark Patteson, and Andrew Slivka for their research assistance. This research project was supported by the Riksbankens Jubileumsfond, Grant M13-0559:1, PI: Staffan I. Lindberg, V-Dem Institute, University of Gothenburg, Sweden; the Knut and Alice Wallenberg Foundation to Wallenberg Academy Fellow Staffan I. Lindberg, Grant 2013.0166, V-Dem Institute, University of Gothenburg, Sweden; European Research Council, Grant 724191, PI: Staffan I. Lindberg, V-Dem Institute, University of Gothenburg, Sweden; and internal grants from the Vice-Chancellor's office, the Dean of the College of Social Sciences, and the Department of Political Science at University of Gothenburg. We performed simulations and other computational tasks using resources provided by the Notre Dame Center for Research Computing (CRC) through the High Performance Computing section and the Swedish National Infrastructure for Computing (SNIC) at the National Supercomputer Centre, SNIC 2016/1-382 and 2017/1-68. We specifically acknowledge the assistance of In-Saeng Suh at CRC and Johan Raber at SNIC in facilitating our use of their respective systems.
\end{abstract}




\section{Abstract}

Theory predicts democracy should reduce corruption. Yet, numerous scholars have found empirically that corruption decreases at high levels of democracy but actually increases at low levels. A key weaknesses of studies that aim to explain this inverted curvilinear relationship, however, is that they do not disaggregate the complex concept of democracy. By contrast, this working paper disaggregates democracy theoretically and empirically. Our theoretical framework shows how components of democracy affect costs and benefits of engaging in corruption and, therefore, the level of corruption overall. Whereas other studies examine only how democratic accountability imposes costs on those engaging in corruption and thus illuminate only the downward curve of the relationship, we also examine the transaction costs and political support benefits of corruption and therefore can explain the initial uptick in corruption at low levels of democracy. Using measures of democratic components from Varieties of Democracy, we examine 173 countries from 1900 to 2012 and find that freedoms of expression and association exhibit the inverted curvilinear relationship with corruption, and that judicial constraints have a negative linear relationship. Moreover, the introduction of elections and the quality of elections act jointly, but each in a linear fashion. The mere introduction of elections increases corruption, thus accounting for the upward sloping segment of the inverted curve. Once the quality of elections begins to improve, corruption decreases, resulting in the downward-sloping segment of the curve. 


\section{Introduction}

Democracy, or responsive government, should in theory also mean less corrupt government. Initial statistical research provided support for this idea, finding a negative linear relationship between democracy and corruption. ${ }^{2}$ Subsequent research, however, revealed a more complicated relationship. Scholars have found that while very high levels of democracy reduce corruption, low to modest levels of democracy actually increase corruption. ${ }^{3}$ In other words, there is an inverted curvilinear relationship, rather than a negative linear one, between corruption and democracy.

Competing explanations for the curvilinear relationship populate the field. Montinola and Jackman question whether this relationship actually exists, worrying that it merely "may reflect the increase in information and reporting of corruption that typically accompanies democratization". ${ }^{4}$ Other scholars accept the paradox and seek to explain it. Focusing on bureaucratic corruption ("state administrative capacity"), Bäck and Hadenius argue that the infusion of freedom accompanying democratization initially increases corruption because authoritarian controls "from above" dissolve without comprehensive democratic checks on officials' behavior "from below" such as electoral participation and public access to information. ${ }^{5}$ Charron and Lapuente contend that the curvilinearity stems from an interaction effect between GDP per capita (which drives citizens' demand for quality of government, the specific outcome variable they consider) and democracy (which drives the supply of leaders willing to enact non-corruption reforms). Their conclusion is that we should expect democracy to decrease corruption but only in rich countries. ${ }^{6}$ Related to this puzzle of curvilinearity, Keefer explains that young democracies exhibit more corruption than old democracies because political candidates in the former rely on clientelism to compensate for their inability to make credible preelectoral promises. ${ }^{7}$

One key weakness of studies that aim to explain the curvilinear relationship is that few disaggregate the complex concept of democracy. Theoretically, authors identify conditions in democratic regimes that cultivate or hinder corruption, always defining democracy broadly (e.g., "political democracy in a liberal sense" in Back and Hadenius 2008). Empirically, there is also a lack of disaggregation, as most scholars rely on composite indices of democracy rather than

\footnotetext{
2 Goldsmith 1999, Sandholtz and Koetzle 2000, Treisman 2000.

3 Bäck and Hadenius 2008, Charron and Lapuente 2010, Montinola and Jackman 2002, Sung 2004.

${ }^{4}$ Montinola and Jackman 2002, 163.

${ }^{5}$ Bäck and Hadenius 2008.

${ }^{6}$ Charron and Lapuente 2010.

${ }^{7}$ Keefer 2007.

${ }^{8}$ Bäck and Hadenius 2008.
} 
indicators of individual democratic institutions or features (e.g., Back and Hadenius 2008, Charron and Lapuente 2010 use a combination of Freedom House and Polity scores). ${ }^{9}$ A different set of studies does disaggregate democracy, but each examines only one or two components of democracy and does not seek to explain the overall curvilinear relationship. ${ }^{10}$ Moreover, this research emphasizes how certain democracy components expand accountability of officials to the public and each other and thus increase the costs of engaging in corruption. The problem is that this explains only the decrease, not the increase, found in the curvilinear relationship between democracy and corruption. The literature can thus explain why democracy eventually curbs corruption, but not why an initial shift from autocracy to democracy seems to foster it. In brief, we lack research that unpacks democracy in order understand the mechanisms underpinning the curvilinear relationship between democracy and corruption.

This paper disaggregates democracy theoretically, methodologically, and empirically in order to explain how democracy might initially increase but subsequently decrease corruption. Our theoretical framework describes how specific components of democracy influence individuals' calculations about the costs and benefits of corruption and thus help determine corruption levels in countries. Though a large body of work has examined the decision to engage in corruption as a cost-benefit calculation, ${ }^{11}$ the innovation of this paper is to use a cost-benefit framework to explain how democracy components increase and then decrease corruption levels. Specifically, the existence of some freedom of association and freedom of expression reduce corruption transaction costs, and the introduction of elections means corruption has the appealing benefit to officials of securing funding to shore up their political support. Together, then, a small increase in democracy reduces the transactions costs and increases the benefits of corruption. As others have shown, only at middle to high levels of democracy do democratic accountability relationships truly flourish, increasing the costs and risks of corruption sufficiently that corruption becomes less appealing.

We use the Varieties of Democracy (V-Dem) dataset to disaggregate the concept of democracy empirically and time-series, cross-sectional regression analysis to test hypotheses about the disaggregated relationships. The analysis corroborates nearly all of our expectations. ${ }^{12}$ We find that, collectively, certain components of democracy-the presence of elections, combined with whether they are free and fair, and freedom of expression, freedom of association, and judicial constraints-drive the curvilinear relationship between democracy and

\footnotetext{
${ }^{9}$ Bäck and Hadenius 2008, Charron and Lapuente 2010.

${ }^{10}$ For example, Adserá, et al. 2003, Brunetti and Weder 2003.

${ }^{11}$ For example, Becker and Stigler 1974, Klitgaard 1988, Van Rijckeghem and Weder 2001.

12 Coppedge, et al. 2016c.
} 
corruption, whereas, unexpectedly, the legislative constraints do not seem to contribute. Of those components that do contribute, freedom of expression and freedom of association exhibit a curvilinear relationship with corruption and judicial constraints have a negative relationship. By contrast, the introduction of elections and the quality of elections act jointly, but each in a linear fashion. The mere introduction of elections (regardless of nature and quality) unambiguously increases corruption, thus accounting for the upward sloping segment of the inverted curve. Then, once the quality of elections begins to improve, corruption decreases, resulting in the downward-sloping segment of the curve.

The paper proceeds by first laying out the theoretical framework and our hypotheses. The next section describes the data and methods. We then turn to confirming that the curvilinear relationship found by other scholars is evident from the V-Dem data. The next sections test, first, alternative explanations then our hypotheses. The final section reviews our findings and considers their implications.

\section{Theoretical Framework}

We theorize that different components of democracy and levels of corruption are connected through individuals' calculations about the costs and benefits of engaging in corruption. The emergence or strengthening of specific components of democracy affects the costs or benefits of corrupt acts. Whereas earlier works have examined the costs and benefits of corruption with respect to individual decision-making, ${ }^{13}$ we argue that these individual decisions constitute costbenefit dynamics, and ultimately, the extent of corruption in a country.

We employ the standard definition of corruption - the use of public office for private gain. This includes heads of government and state, cabinet ministers, legislators, judges, and bureaucrats stealing, embezzling or misappropriating public funds or other state resources for personal or family use and granting favors in exchange for bribes, kickbacks or other material inducements. Note that our definition excludes electoral irregularities, such as vote-buying and ballot-stuffing, which do not necessarily involve public officials or private gain. ${ }^{14}$

We consider six components of democracy: the existence of elections, the quality of elections, judicial constraints on the executive, legislative constraints on the executive, freedom of expression, and freedom of association. These components of democracy affect three costs

\footnotetext{
${ }^{13}$ For example, Becker and Stigler 1974, Klitgaard 1988, Van Rijckeghem and Weder 2001.

14 Also see Keefer 2007 for more on the curvilinear relationship between democracy and clientelism. Our theoretical conceptualization of corruption is slightly different than some others used in the literature examining democracy and corruption, such as Back and Hadenius' 2008 focus on bureaucratic corruption, or Charron and Lapuente's 2010 focus on the quality of government.
} 
and benefits of engaging in corruption, specifically accountability costs, transaction costs, and political support benefits.

With respect to accountability costs, democracy components establish three different types of accountability. ${ }^{15}$ The existence of competitive and fair elections allows citizens to reward and punish leaders for their actions in office, ${ }^{16}$ known as vertical accountability. Legislative and judicial constraints on the executive-in the form of self-confident, independent, and capacitated legislatures and high courts with the power to monitor and sanction the executive-create horizontal accountability. ${ }^{17}$ Freedom of expression and freedom of association promote an active and free media and civil society, which facilitate both informed selection by elections and checks and balances between institutions and thus create societal accountability. ${ }^{18}$

As democratic components furthering accountability become more effective, the costs of engaging in corruption increase: illicit behavior is more likely to be discovered and punished and thus the level of corruption decreases. This cannot, however, account for the greater amount of corruption at low to middle levels of democracy relative to no democracy. Studies of corruption that focus exclusively on accountability thus cannot explain the curvilinear relationship.

By including transaction costs and political support benefits of corruption, our framework accounts for the greater amount of corruption at low to middle levels of democracy. First, when democratic components are introduced, but are not strong enough to ensure effective accountability, they can increase corruption by reducing the transaction costs of engaging in illicit activities. Specifically, when freedom of expression and freedom of association are introduced, but are weak, co-conspirators can more readily identify each other and organize. This allows co-conspirators to develop and execute corruption schemes more easily. In addition, the emergence of some information, in the absence of high levels of transparency (e.g., about government contracts or anticipated government programs), increases opportunities for rentseeking. ${ }^{19} \quad$ These lowered transaction costs facilitate corruption by government executives, legislators, judges, and bureaucrats; officials may collaborate in schemes or work independently with members of the public. In such a situation, freedom of expression and freedom of association are not yet strong enough to ensure accountability. Whereas the corruption literature has examined the cost of losing office, it has focused little attention on this other cost-the transaction costs of corruption.

\footnotetext{
${ }^{15}$ Lindberg, et al. 2017.

${ }^{16}$ For example, Dahl 1971.

${ }^{17}$ For example, Karl and Schmitter 1991, Laver and Shepsle 1999, O'Donnell 1998.

${ }^{18}$ For example, Schedler 1999, Smulovitz and Peruzzotti 2000.

19 Bac 2001, Hollyer, et al. 2011.
} 
Then, as freedom of expression and freedom of association increase, a well-organized corruption network is offset by accountability mechanisms and declining opportunities for rentseeking. Access to information, through the media and civil society, provides societal accountability and facilitates vertical accountability. Media freedom and media access provide citizens with information about corrupt acts and viable avenues for reporting and punishing corruption. ${ }^{20}$ This information can also be passed from person to person or through civil society when freedom of expression is high, and freedom of association provides greater potential for facilitating collective action in reaction to knowledge about corruption. Societal accountability discourages corruption among government executives, legislators, judges, and bureaucrats, and vertical accountability deters those who are elected from engaging in corruption. The free flow of information finally reduces officials' and bureaucrats' ability to use or sell information for personal gain. ${ }^{21}$ Societal accountability discourages corruption among government executives, legislators, judges, and bureaucrats, and vertical accountability deters those who are elected from engaging in corruption.

From this discussion of how democracy components through accountability and transaction costs and transactions benefits affect corruption levels, we derive our first four hypotheses. Because freedom of expression and freedom of association, at their weakest, reduce transactions costs of engaging in corruption and, at their strongest, increase accountability costs of engaging in corruption, we hypothesize,

\section{H1: There is a curvilinear relationship between freedom of expression and corruption.}

\section{H2: There is a curvilinear relationship between the freedom of association and corruption.}

Our theoretical framework suggests that legislative and judicial constraints would provide horizontal accountability and increases the transaction costs of corruption. Specifically, judiciaries and legislatures are internal monitors and constraints on the behavior of officials and bureaucrats to help ensure that they do not abuse their offices. ${ }^{22}$ The separation of powers also tends to reduce opportunities for personal gain by increasing the number of players who would have to be involved, thus making deals more complicated and costly for the parties in the

20 Adserá, et al. 2003, Lederman, et al. 2005, Sandholtz and Koetzle 2000.

21 Adsera et al. 2003, Kolstad and Wiig 2011, Brunetti and Weder 2003.

22 Rose-Ackerman 1996. 
corrupt exchange. $^{23}$ As a result, the level of illicit activity in the judiciary and legislature decreases as judges and legislators independently monitor the executive and bureaucrats rather than collude in corruption. The level of executive corruption falls as legislative and judicial constraints on the executive effectively act as a deterrent to corruption. These constraints reduce overall corruption by having an impact on legislative, judicial, executive, but likely not bureaucratic, corruption. So, we hypothesize that

H3: There is a negative relationship between judicial constraints on the executive and corruption.

\section{H4: There is a negative relationship between legislative constraints on the executive and corruption.}

The benefit of political support is also important to consider because, like transaction costs, it contributes to the increase in corruption found in the curvilinear relationship. The introduction of elections, regardless of how free and fair they are, motivates government officials to engage in illicit activities to raise funds for garnering political support. By transferring public funds and other state resources and grant favors to those whose loyalty they need, autocrats can reduce the threat posed by elections. Even when election "results" are controlled from above, the electoral process can serve as rallying points for the disgruntled and can spark revolutions that oust incumbents. ${ }^{24}$ When leaders' control of elections is imperfect, they can suffer actual electoral defeat. In either case, they have an incentive to transfer public funds and state resources and to grant favors to potential and current supporters in order to help them maintain their positions. This is most apt for officials whose positions are newly subject to elections but the uncertainty of a new selection process for some officials can encourage even non-elected ones to shore up their political support. Political support manifests itself, most broadly, in inaction, that is in not initiating insurgencies, not carrying out coups, and not using one's executive, legislative, or judicial authority to remove someone from power, for example. ${ }^{25}$ Following from this logic, we propose a fifth hypothesis,

\section{H5: There is a positive relationship between holding elections and corruption.}

\footnotetext{
${ }^{23}$ Kolstad and Wiig 2016, Rose-Ackerman 1996.

${ }^{24}$ Kuntz and Thompson 2009, Tucker 2007.

25 As noted above, our focus is not electoral corruption and thus our understanding of political support is broader than vote-buying.
} 
When elections not only exist, but are increasingly free and fair, the vertical accountability mechanism work more effectively, counteracting the political support benefit of corruption. In free and fair elections, voters are better able, than in noncompetitive, manipulated elections, to hold corrupt officials accountable for their actions by removing them from office and not reelecting corrupt officials. ${ }^{26}$ Those who have been engaging in illicit activities to shore up their positions are held accountable for doing so. Because of these costs, political leaders tend to eschew corrupt practices in order to remain in office and more readily punish their peers or bureaucrats who engage in corrupt activities. ${ }^{27}$ For these reasons, we include a sixth, and final, hypothesis,

\section{H6: There is a negative relationship between the quality of elections and corruption.}

When the relationships described in $\mathrm{H} 5$ and $\mathrm{H} 6$ are combined, a curvilinear relationship should be revealed.

The inclusion of the benefits of political support underscores, as our empirical results show, that it is not just bureaucrats, but also top government officials, who contribute to the increase in corruption. By contrast, Bäck and Hadenius attribute the increase to the weakening of authoritarian controls from above. ${ }^{28}$ But, their explanation accounts for only an increase in bureaucratic corruption. By considering the value of corruption to political support, our framework also accounts for why top government leaders engage in more corruption as components of democracy emerge.

\section{Data and Methods}

To test our hypotheses regarding the relationship between democracy and corruption, we use the V-Dem dataset, which provides data for 173 countries from 1900 to $2012 .{ }^{29}$ This provides a longer time-series and greater number of disaggregated data points to study this relationship than datasets used in earlier corruption studies. The indices we create and use are comprised of V-Dem expert-coded indicators. For each indicator, V-Dem enlists a minimum of five experts per country-year with documented expertise in the particular area. A customized measurement

\footnotetext{
26 Barro 1973, Ferejohn 1986, Kolstad and Wiig 2016.

${ }^{27}$ Adserá, et al. 2003, Sandholtz and Koetzle 2000.

28 Bäck and Hadenius 2008.

${ }^{29}$ Version 6.2. Coppedge, et al. 2016a.
} 
model using Bayesian ordinal item response theory aggregates these responses into one indicator-country-year observation. The measurement model weights each coder by a reliability parameter, determined by the coder's level of agreement with other country coders. ${ }^{30}$

\section{Dependent Variable}

The dependent variable in all hypotheses is corruption, which we operationalize by combining six V-Dem indicators—executive bribery, executive embezzlement, public sector bribery, public sector embezzlement, legislative corruption, and judicial corruption-into Corruption Index. ${ }^{31}$ Summary statistics for all variables appear in Table 1 of the supplemental appendix. More details about this index and the other variables used in this paper can be found in the appendix at the end of the paper and the V-Dem Codebook. ${ }^{32}$ An extensive discussion regarding the validity of the V-Dem corruption index can be found in Strategies of Validation: Assessing the Varieties of Democracy Corruption Data. ${ }^{33}$

\section{Independent Variables}

To validate that the curvilinear relationship found by other studies using different data is replicated using the V-Dem dataset, we measure democracy using V-Dem's Electoral Democracy index..$^{34}$

To test $\mathrm{H} 1$ and H2, we employ two V-Dem indices. Freedom of Expression is an index formed by taking the point estimates from a Bayesian factor analysis model of the indicators for print/broadcast censorship effort, internet censorship effort, harassment of journalists, media bias, media self-censorship, the level of critical discourse in print/broadcast media, the balance in perspectives in print/broadcast media, freedom of discussion for men/women, and freedom of academic and cultural expression. This operationalization of freedom of expression aligns with our theory that both information availability and information neutrality are necessary in order to have high freedom of expression. Freedom of Association is an index formed by taking the point estimates from a Bayesian factor analysis model of the indicators for party ban, barriers to parties, opposition party autonomy, elections multiparty, CSO entry and exit, and CSO repression. Reflecting the role that freedom association plays in determining both transaction

\footnotetext{
${ }^{30}$ Coppedge, et al. 2016b, Pemstein, et al. 2015.

31 As legislative corruption data are missing for countries lacking legislatures, we take the average of public sector corruption, executive corruption, and judicial corruption to create the corruption index in these cases. McMann, et al. 2016.

32 Coppedge, et al. 2016a.

33 McMann, et al. 2016.

${ }^{34}$ For more discussion about the V-Dem democracy indices, see Teorell, et al. 2016.
} 
costs and risks of detection and punishment, this index takes into account the organizational costs for forming parties and CSOs as well as any ongoing barriers to operation that might hinder an environment of accountability.

To test $\mathrm{H} 3$ and H4, we use two more indices from V-Dem. Judicial Constraints on Executive is an index formed by taking the point estimates from a Bayesian factor analysis model of the indicators for executive respects constitution, compliance with judiciary, compliance with high court, high court independence, and lower court independence. Legislative Constraints on Executive is an index formed by taking the point estimates from a Bayesian factor analysis model of the indicators for legislature questions officials in practice, executive oversight, legislature investigates in practice, and legislature opposition parties. Each of these indices captures multiple mechanisms of horizontal accountability that might limit corruption.

For H5 and H6, we analyze two variables tapping into different aspects of the theory. The variable Electoral Regime is a binary indicator for whether or not a country has introduced elections, and provides an independent variable for H5. Reduced Free and Fair Elections is an index formed by taking the point estimates from a principal components factor analysis model of the indicators for election management body (EMB) autonomy, EMB capacity, voter registry, other voting irregularities, election government intimidation, electoral violence, and whether or not the election was generally free and fair. Departing from the higher-level free and fair elections index produced in V-Dem, we exclude vote buying, as other scholars have considered vote buying to be an alternative measure of corruption or have considered it to be one specific form of corruption. $^{35}$

\section{Control Variables}

We consider a broad set of control variables known to affect the relationship between democracy and corruption. As an overview of all control variables, we provide a diagram, Figure 1 , in the supplemental appendix.

We control for three time-invariant factors with country-fixed effects. ${ }^{36}$ British colonial heritage and Protestantism are often found to be associated with higher levels of democracy and lower levels of corruption. ${ }^{37}$ By contrast, ethnic heterogeneity is typically correlated with lower

\footnotetext{
35 See, respectively, Keefer 2007, Van Ham and Lindberg 2016.

36 Protestantism and ethnic heterogeneity are time-invariant in most datasets, including in V-Dem, though they are not time-invariant theoretically.

37 Gerring and Thacker 2005, Lipset and Lenz 2000, Treisman 2007.
} 
levels of democracy and higher levels of corruption. ${ }^{38}$ We also control for year-specific effects using year-fixed effects.

We consider two political control variables, which are both time-variant. In all of our regressions, we control for the number of years a country has been a democracy (Stock of Democracy). This allows us to separate the effect of accountability levels from the effect, simply, of becoming more experienced with democracy, as countries more experienced with democracy may be better able to utilize democratic accountability mechanisms. State capacity is a potential confound because it could affect both corruption levels and the potential for democracy in a society. ${ }^{39}$ To control for State Capacity, we use the Hansen and Sigman state capacity index, the most expansive dataset on state capacity that is available. ${ }^{40}$ The coverage of this dataset is still limited, so we do not include state capacity in our main analyses. However, Table 2 of the supplemental appendix includes robustness checks with state capacity included. ${ }^{41}$

Finally, we include three economic controls, all of which are time-variant. Income (GDP per Capita), income equality (GINI Coefficient), and Trade Openness have each been shown to have a positive relationship with level of democracy and a negative one with corruption. ${ }^{42}$ As with the state capacity data, data on GDP per capita, inequality, and trade openness are not available for the expansive number of countries and years for which we have V-Dem data. However, we run our analyses in Table 2 of the supplemental appendix with all three of these economic control variables included.

Because many of the control variables often come from sparser datasets the effect of democracy components on corruption often disappears when we include control variables. However, when we use the same sample, but without the control variables, the lack of significant findings persists, which tells us that the reduction in observations is driving the loss of significance, and not the inclusion of controls. All of these robustness checks can be found in Table 2 of the supplemental appendix.

\section{Modelling Strategy}

All regressions include two lags of the dependent variable (to purge the residuals due to serial autocorrelation), year- and country- fixed effects, and clustered standard errors at the country

\footnotetext{
38 Cornwell 1964, Huntington 2002, Kitschelt and Wilkinson 2007.

39 Klitgaard 1988, Rose-Ackerman 1999.

${ }^{40}$ Hanson and Sigman 2013.

${ }^{41}$ We would like to control for the effect of trust, which has been shown to affect both democracy and corruption levels in societies (Bjørnskov and Paldam 2005; Morris and Klesner 2010). However, there are not adequate timeseries, cross-national data on trust available for inclusion in our analysis.

42 Ades and Di Tella 1999, Gerring and Thacker 2005, Sandholtz and Gray 2003, Sandholtz and Koetzle 2000.
} 
level. We replicate our findings without five outlier cases in Table 3 in the supplemental appendix, and the results are robust to their exclusion.

Due to the high level of serial autocorrelation, short-run (one-year lagged) effects of democracy components on corruption appear substantively insignificant, even if statistically significant. As corruption is a sticky phenomenon, the effect of democracy on corruption levels should be expected to be felt primarily over a long-term period. To capture this idea and depict the long-run effects visually, we calculate the long-run effects by aggregating the effect of the independent variable in question over time.

\section{The Curvilinear Relationship}

Prior to testing our hypotheses, we validate the presence of a curvilinear relationship between democracy and corruption in the V-Dem data. Prior research has provided evidence of three curvilinear relationships. Scholars have found an inverted U-shaped curve, where corruption levels are low in the most authoritarian and the most democratic states; an inverted J-shaped curve, where corruption levels are the lowest in the most democratic states; or an S-shaped curve, where there is an initial drop in corruption with liberalization in the most authoritarian countries. ${ }^{43}$ It is important to note that $\mathrm{J}$ - and U-shaped relationships are statistically identicalboth have a significant squared term. The only difference is whether the y-intercept it located close to the right-most expected value, where $\mathrm{x}$ it at its maximum. The theoretical and substantive difference between the J-and U-shaped curves are minimal: what is key is that the relationship is non-monotonic. The previous finding of an S-shaped curve by one scholar is problematic substantively as there is no compelling theory, including our own, as to why we would expect an S curve.

The V-Dem data show a strong inverted J-shaped relationship between corruption and democracy (Figure 1). Corruption increases as democracy increases from 0 to approximately 0.5 (on a scale of 0 to 1 ), what would be a hybrid regime displaying some weak components of democracy. From 0.5 to 1 , increases in democracy are associated with decreases in corruption. In Table 1 we take further steps to test the robustness of this relationship and find that it remains. First, we introduce controls for serial dependence and potential backwards causality by introduction lagged dependent variables and lagged democracy variables, as well as controlling for possible global co-trending of democracy and corruption by introducing year-fixed effects (Model 1). Next, to further reduce threats to inference from omitted variable bias, we exclusively

\footnotetext{
${ }^{43}$ For example, see, respectively, Bäck and Hadenius 2008, Montinola and Jackman 2002, Sung 2004.
} 
restrict attention to within-country variation by also incorporating country-fixed effects (Model 2). The relationship also remains largely unchanged when outliers are removed, as demonstrated in Table 3 in the supplemental appendix.

Figure 1: Scatter Plot of Democracy and Corruption

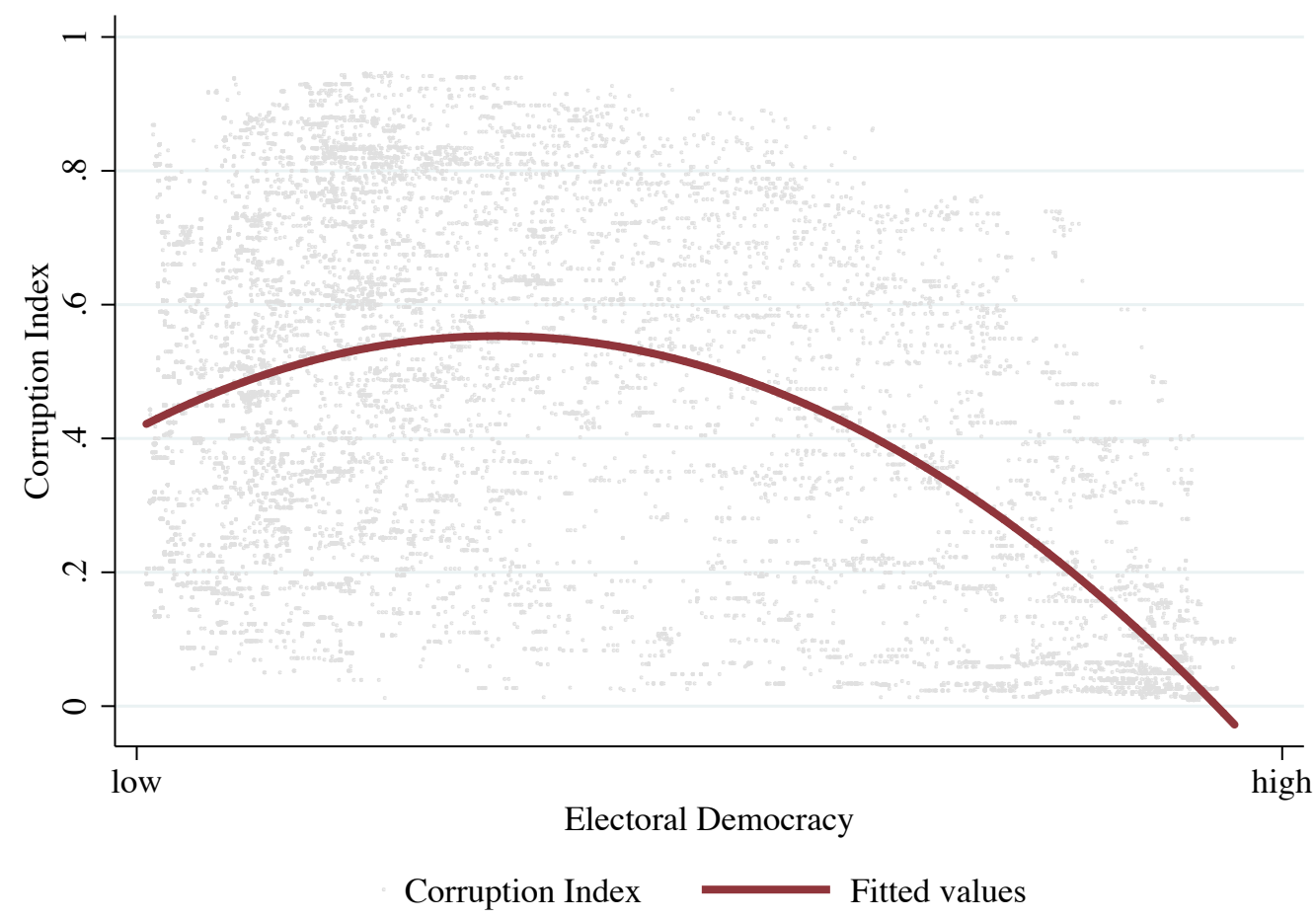




\begin{tabular}{|c|c|c|c|c|c|}
\hline & $\begin{array}{l}(1) \\
\text { Corr. } \\
\text { Index }\end{array}$ & $\begin{array}{l}(2) \\
\text { Corr. } \\
\text { Index }\end{array}$ & $\begin{array}{l}\text { (3) } \\
\text { Corr. } \\
\text { Index }\end{array}$ & $\begin{array}{l}(4) \\
\text { Corr. } \\
\text { Index }\end{array}$ & $\begin{array}{l}\text { (5) } \\
\text { Exec. Corr. }\end{array}$ \\
\hline $\begin{array}{l}\text { Corruption Index, Lagged (1 } \\
\text { Year) }\end{array}$ & $\begin{array}{l}1.0513^{* * *} \\
(0.0149)\end{array}$ & $\begin{array}{l}1.0344^{* * *} \\
(0.0148)\end{array}$ & $\begin{array}{l}1.0365^{* * *} \\
(0.0168)\end{array}$ & $\begin{array}{l}1.0366^{* * *} \\
(0.0168)\end{array}$ & \\
\hline $\begin{array}{l}\text { Corruption Index, Lagged (2 } \\
\text { Years) }\end{array}$ & $\begin{array}{l}-0.0615^{* * *} \\
(0.0149)\end{array}$ & $\begin{array}{l}-0.0628^{* * *} \\
(0.0151)\end{array}$ & $\begin{array}{l}-0.0812^{* * *} \\
(0.0160)\end{array}$ & $\begin{array}{l}-0.0810^{* * *} \\
(0.0160)\end{array}$ & \\
\hline $\begin{array}{l}\text { Executive Corruption, Lagged } \\
\text { (1 Year) }\end{array}$ & & & & & $\begin{array}{l}1.0449^{* * *} \\
(0.0166)\end{array}$ \\
\hline $\begin{array}{l}\text { Executive Corruption, Lagged } \\
\quad(2 \text { Years })\end{array}$ & & & & & $\begin{array}{l}-0.0974^{* * *} \\
(0.0162)\end{array}$ \\
\hline $\begin{array}{l}\text { Electoral Democracy Lagged (1 } \\
\quad \text { Year) }\end{array}$ & $\begin{array}{l}0.0144^{* * *} \\
(0.0031)\end{array}$ & $\begin{array}{l}0.0327^{* * *} \\
(0.0055)\end{array}$ & $\begin{array}{l}0.0136^{*} \\
(0.0080)\end{array}$ & $\begin{array}{l}0.0147^{*} \\
(0.0080)\end{array}$ & $\begin{array}{l}0.0210^{* *} \\
(0.0099)\end{array}$ \\
\hline Electoral Democracy ${ }^{\wedge} 2$ & $\begin{array}{l}-0.0230^{* * *} \\
(0.0036)\end{array}$ & $\begin{array}{l}-0.0344^{* * *} \\
(0.0059)\end{array}$ & $\begin{array}{l}-0.0257^{* * *} \\
(0.0088)\end{array}$ & $\begin{array}{l}-0.0275^{* * *} \\
(0.0092)\end{array}$ & $\begin{array}{l}-0.0385^{* * *} \\
(0.0120)\end{array}$ \\
\hline $\begin{array}{l}\text { Stock of Democracy, Lagged (1 } \\
\quad \text { Year) }\end{array}$ & & & $\begin{array}{l}0.0016^{* * *} \\
(0.0005)\end{array}$ & $\begin{array}{l}0.0016^{* * *} \\
(0.0005)\end{array}$ & $\begin{array}{l}0.0025^{\text {*** }} \\
(0.0007)\end{array}$ \\
\hline $\begin{array}{l}\text { GDP Per Capita, Lagged (1 } \\
\text { Year) } \\
\text { GDP Per Capita x Electoral } \\
\text { Democracy }\end{array}$ & & & $\begin{array}{l}-0.0002 \\
(0.0001)\end{array}$ & $\begin{array}{l}-0.0003 \\
(0.0004) \\
0.0002 \\
(0.0004)\end{array}$ & $\begin{array}{l}-0.0009^{*} \\
(0.0005) \\
0.0009 \\
(0.0005)\end{array}$ \\
\hline $\mathrm{R}^{2}$ & 0.9882 & 0.9538 & 0.9324 & 0.9324 & 0.9117 \\
\hline No. Countries & 173 & 173 & 154 & 154 & 154 \\
\hline Avg. Years per Country & 91.4 & 91.4 & 66.3 & 66.3 & 66.3 \\
\hline No. Observations & 15818 & 15818 & 10208 & 10208 & 10208 \\
\hline
\end{tabular}

Entries are regression coefficients, with standard errors clustered on countries, in parentheses. Country- and yearfixed effects included in regressions but omitted from the table.

${ }^{*} p<0.10,{ }^{* *} p<0.05,{ }^{* * *} p<0.01$

We do not find evidence of an S-curve. Using a third-order functional form, Sung finds a S-shaped relationship between democracy and corruption, in that there are negative coefficients on the linear, squared, and cubic terms. ${ }^{44}$ When we use a cubic functional form, we find a positive linear, negative squared, and positive cubic terms. These results are available in Table 4 of the supplemental appendix.

In sum, the V-Dem data generate a curve similar to most of the literature, which has found either an inverted J- or U- curve. We consistently find an inverted J-curve, which again is nearly identical statistically to the inverted U-curve. 


\section{Alternative Explanations}

While we examine the same puzzling curve as much of the literature, our explanation is different. Before testing the hypotheses derived from our theoretical framework, we test alternative explanations using V-Dem data. First we control for Stock of Democracy and GDP per Capita (Model 3, Table 1 above). The results refute the notion, implied by Treisman and Keefer, that the curvilinear relationship between democracy and corruption might be driven by the relationship between a country's experience with democracy and its level of corruption. ${ }^{45}$ As can be seen, even after controlling for Stock of Democracy, the curvilinear relationship still holds, and the coefficient for Stock of Democracy is not in the expected direction: it is positive, implying that more experience with democracy, all else equal, actually leads to increases in corruption.

In Model 4, we also refute Charron and Laupente's argument that the curvilinear relationship is produced by an interaction effect between GDP and (electoral) democracy. ${ }^{46}$ Though they are considering the broader outcome variable of "Quality of Government," rather than corruption, it is nonetheless compelling to note the statistically insignificant coefficient on the GDP per Capita*Electoral Democracy interaction term.

Finally, in Model 5, we examine the implication of Bäck and Hadenius' argument that public sector corruption drives the relationship between democracy and corruption. ${ }^{47}$ Even when excluding public sector corruption from the dependent variable and focusing on only corruption in the executive, Executive Corruption, the effect holds.

\section{Results}

Unable to account for the inverted J-curve relationship between corruption and democracy with existing explanations, we turn to our hypotheses. First, our theoretical framework predicts that the inverted J-shaped relationship should be present when considering the effect of Freedom of Expression and Freedom of Association on corruption (H1 and $\mathrm{H} 2$, respectively). We find strong support for both of these hypotheses. In both Model 1 and Model 2 of Table 2, there is a significant and positive coefficient on the linear term and a significant and negative coefficient on the squared term.

\footnotetext{
${ }^{45}$ Keefer 2007, Treisman 2007.

${ }^{46}$ Charron and Lapuente 2010.

47 Bäck and Hadenius 2008.
} 
Table 2: Freedom of Expression, Freedom of Association, and Corruption

\begin{tabular}{llll}
\hline & $\mathbf{( 1 )}$ & $\mathbf{( 2 )}$ & $\mathbf{( 3 )}$ \\
\hline Corruption Index, Lagged (1 Year) & $1.0345^{* * *}$ & $1.0347^{* * *}$ & $1.0022^{* * *}$ \\
Corruption Index, Lagged (2 Years) & $(0.0149)$ & $(0.0150)$ & $(0.0183)$ \\
& $-0.0615^{* * *}$ & $-0.0611^{* * *}$ & $-0.0776^{* * *}$ \\
Freedom of Expression, Lagged (1 Year) & $(0.0152)$ & $(0.0151)$ & $(0.0155)$ \\
& $0.0217^{* * *}$ & & $0.0243^{*}$ \\
Freedom of Expression^2 & $(0.0061)$ & & $(0.0132)$ \\
& $-0.0230^{* * *}$ & & $-0.00567^{*}$ \\
Media Freedom, Whitten-Woodring and Van Belle & $(0.0063)$ & & $(0.0132)$ \\
& & & $-0.0057^{* * *}$ \\
Freedom of Association, Lagged (1 Year) & & & $(0.0019)$ \\
& & $0.0262^{* * *}$ & \\
Freedom of Association^2 & & $(0.0059)$ & $-0.0256^{* * *}$ \\
& & $(0.0062)$ & \\
\hline $\mathrm{R}^{2}$ & & 0.9538 & 0.9044 \\
No. Countries & & 173 & 168 \\
Avg. Years per Country & & 51.2 \\
No. Observations & & & 8604 \\
\hline
\end{tabular}

Entries are regression coefficients, with standard errors clustered on countries, in parentheses. Country- and yearfixed effects included in regressions but omitted from the table.

${ }^{*} p<0.10,{ }^{* *} p<0.05,{ }^{* * *} p<0.01$

However, it is reasonable to be cautious when interpreting our finding on Freedom of Expression. As Montinola and Jackman point out, any positive relationship between democracy and corruption "may reflect the increase in information and reporting of corruption that typically accompanies democratization." 48 As the V-Dem Freedom of Expression index includes several indicators that pertain to the availability of information in the media, one might be concerned that this index is serving as a proxy indicator for the attention the issue of corruption is getting in the media. Accordingly, we acknowledge that the results regarding freedom of expression presented in Table 2 may demonstrate a curvilinear relationship between freedom of expression and corruption, or alternatively, may demonstrate simply that there is a curvilinear relationship between media attention on corruption and expert coder ratings of corruption. However, there are two reasons we believe the results on freedom of expression support our hypothesis. First, the concern that Montinola and Jackman point to implies a positive, linear relationship between media attention on corruption and coder perceptions, and what we find is a curvilinear relationship implying that after a certain threshold freedom of expression does hurt corruption. ${ }^{49}$ Second, when we include a measure of media freedom from outside the V-Dem dataset, Media Freedom from Whitten-Woodring and Van Belle, as a control variable capturing

48 Montinola and Jackman 2002, 163.

49 Montinola and Jackman 2002. 
specifically changes in media scrutiny, the relationship between freedom of expression and corruption holds (Model 3).

In Table 3, we turn to our tests of $\mathrm{H} 3$ and $\mathrm{H} 4$ examining the relationships between judicial and legislative constraints, respectively, and corruption. In these models, we control for the Electoral Democracy and its squared term, so as to isolate the horizontal accountability mechanism from the vertical accountability mechanism. Model 1 shows that Judicial Constraints on Executive negatively impacts corruption, supporting H3. However, failing to support H4, Model 2 shows no significant effect for Legislative Constraints on Executive.

Table 3: Judicial and Legislative Constraints on the Executive and Corruption

\begin{tabular}{lll}
\hline & $\mathbf{( 1 )}$ & $\mathbf{( 2 )}$ \\
\hline Corruption Index, Lagged (1 Year) & $1.0307^{* * *}$ & $1.0191^{* * *}$ \\
& $(0.0149)$ & $(0.0162)$ \\
Corruption Index, Lagged (2 Years) & $-0.0622^{* * *}$ & $-0.0632^{* * *}$ \\
& $(0.0150)$ & $(0.0155)$ \\
Electoral Democracy, Lagged (1 Year) & $0.0386^{* * *}$ & $0.0315^{* * *}$ \\
& $(0.0062)$ & $(0.0076)$ \\
Electoral Democracy^2 & $-0.0425^{* * *}$ & $-0.0395^{* * *}$ \\
& $(0.0063)$ & $(0.0078)$ \\
Judicial Constraints on Executive, Lagged (1 Year) & $-0.0074^{* *}$ & \\
Legislative Constraints on Executive, Lagged (1 Year) & $(0.0032)$ & -0.0046 \\
& & $(0.0033)$ \\
\hline $\mathrm{R}^{2}$ & 0.9539 & 0.9354 \\
No. Countries & 173 & 172 \\
Avg. Years per Country & 94.4 & 74.6 \\
No. Observations & 15818 & 12830 \\
\hline En & & \\
\hline
\end{tabular}

Entries are regression coefficients, with standard errors clustered on countries, in parentheses. Country- and yearfixed effects included in regressions but omitted from the table.

${ }^{*} p<0.10,{ }^{* *} p<0.05,{ }^{* * *} p<0.01$

Finally, we test our hypotheses regarding the effect of electoral mechanisms, H5 and H6. We start in Model 1 in Table 4 by testing H5, the idea that there is a direct positive effect of elections on corruption. We find that electoral regimes, without any other pieces of democracy included, are more corrupt, corroborating H5. In Model 2 in Table 4, we test H6 by allowing the Electoral Regime variable to hold a linear relationship with corruption and then adding only the linear Reduced Free and Fair Elections term. The result still holds. In line with H5, the mere introduction of elections as compared to closed authoritarian regimes is positively related to corruption. This, we argue, is one of the key explanations for the upward bend of the inverted Jshaped relationship between electoral democracy and corruption. Then, controlling for whether elections are held, and in line with H6, election quality is negatively related to corruption, in line 
with previous theorizing of the corruption-purifying effect of vertical accountability. This helps account for the downward bend of the inverted $\mathrm{J}$.

Table 4: Explaining the Relationship between Corruption and Electoral Democracy

\begin{tabular}{lll}
\hline & $\mathbf{( 1 )}$ & $\mathbf{( 2 )}$ \\
\hline Corruption Index, Lagged (1 Year) & $1.0365^{* * *}$ & $1.0346^{* * *}$ \\
& $(0.0149)$ & $(0.0148)$ \\
Corruption Index, Lagged (2 Years) & $-0.0615^{* * *}$ & $-0.0621^{* * *}$ \\
& $(0.0151)$ & $(0.0151)$ \\
Electoral Regime, Lagged (1 Year) & $0.0031^{* * *}$ & $0.0051^{* * *}$ \\
& $(0.0010)$ & $(0.0013)$ \\
Reduced Free and Fair Elections, Lagged (1 Year) & & $-0.0072^{* *}$ \\
& & $(0.0028)$ \\
\hline $\mathrm{R}^{2}$ & 0.9537 & 0.9537 \\
No. Countries & 173 & 173 \\
Avg. Years per Country & 91.4 & 91.4 \\
No. Observations & 15818 & 15812 \\
\hline Entries are regression coefficients, with standard errors clustered on countries, in parentheses. Country- and year- \\
fixed effects included in regressions but omitted from the table. \\
${ }^{*} p<0.10,{ }^{* *} p<0.05,{ }^{* * *} p<0.01$ &
\end{tabular}

These findings from our hypothesis-testing remain consistent when the additional controls are added. This is evident from Table 2 in the supplemental appendix.

We note that it is rare to see the same data source for both dependent and independent variables. The norm to avoid this practice is not unfounded. One might be concerned about a correlation in measurement error biasing the results of analysis. However, we emphasize four justifications. First, practically speaking, V-Dem's coverage is unparalleled, so we cannot run the analysis with any other data. Second, the V-Dem measurement model is designed to improve cross-country comparability through bridging, lateral coding, and the use of anchoring vignettes. As cross-country differences are a likely primary driver of correlated measurement error, reducing these differences makes the V-Dem data less likely to be plagued by this threat. Third, it may not actually mitigate the issue to substitute in other expert survey data, as other experts may be subject to the same biases as V-Dem experts are, if not more so. For example, if we are concerned that the normative premium placed on democracy in the international community would bias coders to rate corruption in democratic countries lower, we do not necessarily think that V-Dem coders would be more subject to this bias than others. In fact, we suspect the opposite because most V-Dem coders study governance and politics and live in the countries they code; whereas other datasets on corruption and democracy rely heavily on foreigners, often businesspeople, rather than political experts. Nonetheless, we include models that use measures for our independent variables from data sources outside of V-Dem in Table 5 of the supplemental appendix. The results for democracy overall are generally robust to the 
substitution of the variables for non-V-Dem data, as is the negative, linear, significant relationship between the quality of elections and corruption. The results for freedom of association, freedom of expression, judicial constraints on executive, and legislative constraints on executive are not robust when substituting non-V-Dem data, but this is likely due to the smaller sample size. Reductions in sample size range from approximately 40 percent to more than 90 percent.

Fourth, to directly deal with this concern in our analysis, we attempt to correct for this potential endogeneity bias by leveraging another special feature of the V-Dem data: the fact that, in most countries, different country-experts responded to different "surveys," i.e. thematically grouped sets of questions. To the extent that the indicators tapping into corruption appear in other such surveys than the indicators tapping into the constructs measuring our six hypotheses, we can accordingly eliminate country experts responding to questions on both sides of the equation. When we do so, we find that our results, with the exception of the relationship between judicial constraints and corruption, are robust. These tests appear at the end of the supplemental appendix in Table 6.

\section{Conclusion}

In this paper, we consider a puzzle that continues to perplex social scientists and practitioners: why do very high levels of democracy reduce corruption while low to modest levels of democracy actually increase corruption? There have been competing explanations, but previous research seeking to explain the puzzle had not disaggregated the complex concept of democracy. By disaggregating democracy theoretically and empirically, we shed light on the components of democracy that drive the curvilinear relationship with corruption. Most broadly, we theorize that specific components of democracy influence individuals' calculations about the transaction and accountability costs and political support benefits of corruption and thus help determine corruption levels in countries. Specifically, we find that, collectively, certain components of democracy - the presence of elections, combined with whether they are free and fair, and freedom of expression, freedom of association, and judicial constraints—are strongly associated with a curvilinear relationship between democracy and corruption. Freedom of expression and freedom of association each exhibit an inverse J-shaped curvilinear relationship with corruption. By contrast, the introduction of elections and the quality of elections each act in a linear 
fashion—positively and negatively with corruption, respectively—but jointly form a curvilinear relationship. Judicial constraints exhibit a negative linear relationship with corruption.

This research has important theoretical and policy implications. Theoretically, our findings underscore that it is not low levels of "democracy," but rather specific democratic components that fuel corruption-namely the introduction of elections in the absence of ensuring they are free and fair, and low levels of freedom of expression and freedom of association. For policymakers, this is a hopeful finding in the sense that democratization does not have to result in greater corruption. Potentially through ordering of the introduction of democratic components and the strengthening of some components early in the democratization process, a proliferation of illicit activity can be avoided. The fact that even weak judicial constraints are associated with a decline in corruption is particularly promising. Finally, we should not lose sight of the reassuring finding that corruption levels are quite low once all democratic components are strong. In short, democratic responsiveness works. 


\section{References}

Ades, A. and R. Di Tella. (1999). "Rents, Competition, and Corruption." The American Economic Review 89, no. 4: 982-993.

Adserá, A., C. Boix and M. Payne. (2003). "Are You Being Served? Political Accountability and Quality of Government." Journal of Law Economics \& Organization 19, no. 2: 445-490.

Bac, M. (2001). "Corruption, Connections and Transparency: Does a Better Screen Imply a Better Scene?" Public Choice 107, no. 1/2: 87-96.

Bäck, H. and A. Hadenius. (2008). "Democracy and State Capacity: Exploring a J-Shaped Relationship." Governance: An International Journal of Policy Administration and Institutions 21, no. 1: 124.

Barbieri, K., O.M. Keshk and B.M. Pollins. (2009). "Trading Data: Evaluating Our Assumptions and Coding Rules." Conflict Management and Peace Science 26, no. 5: 471-491.

Barro, R.J. (1973). "The Control of Politicians: An Economic Model." Public Choice 14, no. 1: 1942.

Becker, G.S. and G.J. Stigler. (1974). "Law Enforcement, Malfeasance, and Compensation of Enforcers." The Journal of Legal Studies 3, no. 1: 1-18.

Brunetti, A. and B. Weder. (2003). "A Free Press Is Bad News for Corruption." Journal of Public Economics 87, no. 7-8: 1801-1824.

Charron, N. and V. Lapuente. (2010). "Does Democracy Produce Quality of Government?" European Journal of Political Research 49, no. 4: 443-470.

Coppedge, M., J. Gerring, S.I. Lindberg, S.-E. Skaaning, J. Teorell, D. Altman, M. Bernhard, M.S. Fish, A. Glynn, A. Hicken, C.H. Knutsen, K. McMann, P. Paxton, D. Pemstein, J. Staton, B. Zimmerman, F. Andersson, V. Mechkova and F. Miri. (2016a). "V-Dem Codebook V6.2."

Coppedge, M., J. Gerring, S.I. Lindberg, S.-E. Skaaning, J. Teorell, D. Altman, M. Bernhard, M.S. Fish, A. Glynn, A. Hicken, C.H. Knutsen, K. McMann, P. Paxton, D. Pemstein, J. Staton, B. Zimmerman, F. Andersson, V. Mechkova and F. Miri. (2016b). "V-Dem Coding Units V.6."

Coppedge, M., J. Gerring, S.I. Lindberg, S.-E. Skaaning, J. Teorell, D. Altman, M. Bernhard, M.S. Fish, A. Glynn, A. Hicken, C.H. Knutsen, K. McMann, P. Paxton, D. Pemstein, J. Staton, B. Zimmerman, F. Andersson, V. Mechkova and F. Miri. (2016c). "V-Dem Dataset V6.2."

Cornwell, E.E.J. (1964). "Bosses, Machines, and Ethnic Groups." Annals of the American Academy of Political and Social Science 353: 27-39.

Dahl, R. (1971). Polyarchy: Participation and Opposition. New Haven: Yale University Press.

Ferejohn, J. (1986). "Incumbent Performance and Electoral Control." Public Choice 50, no. 1-3: 525.

Gerring, J. and S.C. Thacker. (2005). "Do Neoliberal Policies Deter Political Corruption?" International Organization 59, no. 1: 233-254.

Goldsmith, A.A. (1999). "Slapping the Grasping Hand: Correlates of Political Corruption in Emerging Markets." American Journal of Economics and Sociology 58, no. 4: 865-883.

Hanson, J.K. and R. Sigman. (2013). "Leviathan's Latent Dimensions: Measuring State Capacity for Comparative Political Research." 
Hollyer, J.R., B.P. Rosendorff and J.R. Vreeland. (2011). "Democracy and Transparency." The Journal of Politics 73, no. 4: 1191-1205.

Huntington, S.P. (2002). "Modernization and Corruption." Political Corruption: Concepts \& Contexts. Eds. A. J. Heidenheimer and M. Johnston. New Brunswick, N.J.: Transaction Publishers.

Karl, T. and P. Schmitter. (1991). "Modes of Transition in Latin-America, Southern and EasternEurope." International Social Science Journal 43, no. 2: 269-284.

Keefer, P. (2007). "Clientelism, Credibility, and the Policy Choices of Young Democracies." American Journal of Political Science 51, no. 4: 804-821.

Kitschelt, H. and S. Wilkinson. (2007). "Citizen-Politician Linkages: An Introduction." Patrons, Clients, and Policies: Patterns of Democratic Accountability and Political Competition. Eds. H. Kitschelt and S. Wilkinson. Cambridge: Cambridge University Press.

Klitgaard, R.E. (1988). Controlling Corruption. Berkeley: University of California Press.

Kolstad, I. and A. Wiig. (2016). "Does Democracy Reduce Corruption?" Democratization 23, no. 7: 1198-1215.

Kuntz, P. and M.R. Thompson. (2009). "More Than Just the Final Straw: Stolen Elections as Revolutionary Triggers." Comparative Politics 41, no. 3: 253-272.

Laver, M. and K.A. Shepsle. (1999). "Understanding Government Survival: Empirical Exploration or Analytical Models?" British Journal of Political Science 29: 395.

Lederman, D., N.V. Loayza and R.R. Soares. (2005). "Accountability and Corruption: Political Institutions Matter." Economics and Politics 17, no. 1: 1-35.

Lindberg, S.I., A. Lührmann and V. Mechkova. (2017). "From De-Jure to De-Facto: Mapping Dimensions and Sequences of Accountability." World Development Report No. 112920. World Bank.

Lipset, S.M. and G.S. Lenz. (2000). "Corruption, Culture, and Markets." Culture Matters: How Values Shape Human Progress. Eds. S. P. Huntington and L. E. Harrison. New York: Basic Books.

Maddison, A. (2010). "Statistics on World Population, Gdp and Per Capita Gdp, 1-2008 Ad." U. o. Groningen, http://www.ggdc.net/maddison/Historical_Statistics/vertical-file_02-2010.xls.

McMann, K., D. Pemstein, B. Seim, J. Teorell and S.I. Lindberg. (2016). "Strategies of Validation: Assessing the Varieties of Democracy Corruption Data." Working Paper No. 23. Varieties of Democracy Institute.

Montinola, G.R. and R.W. Jackman. (2002). "Sources of Corruption: A Cross-Country Study." British Journal of Political Science 32: 147-170.

O'Donnell, G. (1998). "Horizontal Accountability in New Democracies." Journal of Democracy 9: 112-126.

Pemstein, D., K.L. Marquardt, F. Miri, E. Tzelgov and Y.-t. Wang. (2015). "The V-Dem Measurement Model: Latent Variable Analysis for Cross-National and Cross-Temporal ExpertCoded Data." Working paper No. 21. Gothenburg: University of Gothenburg.

Rose-Ackerman, S. (1999). Corruption and Government: Causes, Consequences, and Reform. Cambridge: Cambridge University Press.

Rose-Ackerman, S. (1996). "Democracy and 'Grand' Corruption." International Social Science Journal 48, no. 149: 365-380. 
Sandholtz, W. and M.M. Gray. (2003). "International Integration and National Corruption." International Organization 57, no. 4: 761-800.

Sandholtz, W. and W. Koetzle. (2000). "Accounting for Corruption: Economic Structure, Democracy, and Trade." International Studies Quarterly 44: 31-50.

Schedler, A. (1999). "Conceptualizing Accountability." The Self-Restraining State: Power and Accountability in New Democracies. Eds. A. Schedler, L. Diamond and M. F. Plattner. Boulder, Colorado: Lynne Rienner Publishers.

Smulovitz, C. and E. Peruzzotti. (2000). "Societal Accountability in Latin America." Journal of Democracy 11, no. 4: 147-158.

Sung, H.-E. (2004). "Democracy and Political Corruption: A Cross-National Comparison." Crime, Law, and Social Change 41, no. 2: 179-193.

Teorell, J., M. Coppedge, S.-E. Skaaning and S.I. Lindberg. (2016). "Measuring Electoral Demoracy with V-Dem Data: Introducing a New Polyarchy Index." University of Gothenburg.

Treisman, D. (2000). "The Causes of Corruption: A Cross-National Study." Journal of Public Economics 76, no. 3: 399-457.

Treisman, D. (2007). "The Causes of Corruption: A Cross-National Study." The Economics of Transition: The Fifth Nobel Symposium in Economics. Eds. E. Berglöf and G. Roland. New York: Palgrave Macmillan.

Tucker, J.A. (2007). "Enough! Electoral Fraud, Collective Action Problems, and PostCommunist Colored Revolutions." Perspectives on Politics 5, no. 03: 535-551.

UNU-Wider. (2008). "World Income Inequality Database, Version 2.0c." Helsinki.

Van Ham, C. and S.I. Lindberg. (2016). "Choosing from the Menu of Manipulation Explaining Incumbents' Choices of Electoral Manipulation Tactics." Working Paper No. 30. University of Gothenberg: Varieties of Democracy Institute.

Van Rijckeghem, C. and B. Weder. (2001). "Bureaucratic Corruption and the Rate of Temptation: Do Wages in the Civil Service Affect Corruption, and by How Much?" Journal of Development Economics 65, no. 2: 307-331.

Whitten-Woodring, J. and D.A. Van Belle. (2015). "The Correlates of Media Freedom: An Introduction of the Global Media Freedom Dataset." Political Science Research and Methods: 1-10. 


\section{Appendix}

\section{List of Variables}

\section{Dependent Variables}

Corruption Index: This is an index created from indicators of executive bribery, executive embezzlement, public sector bribery, public sector embezzlement, legislative corruption, and judicial corruption using Bayesian factor analysis. This index was rescaled to vary between 0 and 1 and to imply that higher values mean greater corruption. Project manager: Jan Teorell Source: V-Dem, Coppedge, et al. 2016a. (v2x_corr)

Executive Corruption: The index is formed by taking the average of the point estimates from a Bayesian factor analysis model of indicators for executive bribery and executive embezzlement. This index was rescaled to vary between 0 and 1 and to imply that higher values mean greater corruption. Project manager: Jan Teorell. Source: V-Dem, Coppedge, et al. 2016a. (v2x_execorr)

\section{Independent Variables}

Electoral Democracy: This index of democracy takes into account the extent of freedom of association, suffrage, clean elections, the election of the executive, and freedom of expression using V-Dem data. Project manager: Jan Teorell. Source: V-Dem, Coppedge, et al. 2016a. (v2x_polyarchy)

Electoral Regime: A country-year is coded as 1 if regularly scheduled national elections are on course and 0 if either the national election of the executive or parliament has been interrupted or prior to the first election in a country's history. Project managers: Staffan I. Lindberg, Jan Teorell. Source: V-Dem, Coppedge, et al. 2016a. (v2x_elecreg)

Freedom of Association: The index is formed by taking the point estimates from a Bayesian factor analysis model of indicators for party bans, barriers to parties, opposition parties' autonomy, the extent to which elections are multiparty, civil society organization (CSO) entry and exit, and CSO repression. Project managers: Allen Hicken, Michael Bernhard, Jan Teorell. Source: V-Dem, Coppedge, et al. 2016a. (v2x_frassoc_thick)

Freedom of Expression: This index examines the extent to which government respects press and media freedom, the freedom of ordinary people to discuss political matters at home and in the public sphere, and the freedom of academic and cultural expression. Project managers: Svend-Erik Skaaning, Jan Teorell. Source: V-Dem, Coppedge, et al. 2016a. (v2x_freexp_thick)

Judicial Constraints on Executive: This index of V-Dem measures examines to what extent the executive abides by the constitution and court rulings and to what extent the judiciary acts in an independent fashion. Project manager: Jan Teorell. Source: V-Dem, Coppedge, et al. 2016a. (v2x_jucon) 
Legislative Constraints on Executive: This index of V-Dem measures examines to what extent are the legislature and government agencies, such as the comptroller general, able to question, investigate, and oversee the executive. Project manager: Jan Teorell. Source: V-Dem, Coppedge, et al. 2016a. (v2xlg_legcon)

Reduced Free and Fair Elections: This index is formed by taking the point estimates from a principal components factor analysis model of the indicators for EMB autonomy, EMB capacity, voter registry, other voting irregularities, election government intimidation, electoral violence, and whether or not the election was generally free and fair. Departing from the higher-level free and fair elections index produced in V-Dem, we exclude vote buying. Project manager: Staffan Lindberg. Source: V-Dem, Coppedge, et al. 2016a. (v2xel_frefair with v2elvotbuy removed)

\section{Control Variables}

GDP per Capita: The natural log of gross domestic production divided by the population size. Source: Maddison 2010. (e_migdppcln)

Gini Coefficient: A measure of income inequality. Source: UNU-Wider 2008. (e_peginiwi)

Media Freedom: This variable is scored, in paraphrased language, as follows: (0) Not possible to criticize the government or government officials; (1) Social, legal, or economic costs related to such criticisms; (2) Such criticisms are common. The original scale was reversed, and the original categories " 0 " (No effective media) and " 8 " (missing data or social/political disruption makes it impossible to code) were set to missing. Source: Whitten-Woodring and Van Belle 2015. (e_mefree)

State Capacity: This variable is produced using Bayesian latent variables analysis on 24 different indicators of state capacity. Source: Hanson and Sigman 2013. (Capacity)

Stock of Democracy: For this variable the value time $t+1$ is equal to the sum of the value of Electoral Democracy at time $\mathrm{t}+1$ and time $\mathrm{t}$, minus 10 percent of depreciation at time $\mathrm{t}$.

Trade Openness: Exports plus imports divided by real GDP per capita. Source: Maddison 2010. Barbieri, et al. 2009.

Note: Where applicable, names of variables as they appear in the V-Dem dataset are given at the end of each entry. 


\section{Supplemental Appendix}

Table 1. Summary Statistics

\begin{tabular}{lllll}
\hline & Mean & SD & Min. & Max. \\
\hline Corruption Index & 0.439 & 0.264 & 0.009 & 0.946 \\
Executive Corruption & 0.450 & 0.300 & 0.011 & 0.979 \\
Electoral Democracy & 0.321 & 0.281 & 0.008 & 0.958 \\
Freedom of Expression & 0.466 & 0.315 & 0.013 & 0.989 \\
Freedom of Association & 0.468 & 0.332 & 0.022 & 0.968 \\
Judicial Constraints on Executive & 0.516 & 0.290 & 0.005 & 0.992 \\
Legislative Constraints on Executive & 0.467 & 0.304 & 0.023 & 0.987 \\
Electoral Regime & 0.607 & 0.488 & 0.000 & 1.000 \\
Reduced Free and Fair Elections & 0.293 & 0.335 & 0.000 & 0.989 \\
Stock of Democracy & 2.705 & 2.518 & 0.012 & 9.430 \\
State Capacity, Hanson and Sigman & 0.000 & 1.000 & -3.512 & 2.862 \\
GDP per Capita, Maddison Project & 4.441 & 5.370 & 0.203 & 42.916 \\
Gini Coefficient, UNU-WIDER & 41.098 & 10.478 & 15.000 & 73.900 \\
Trade Openness & 0.159 & 0.310 & 0.000 & 6.383 \\
Freedom House and Polity Index & 5.389 & 3.454 & 0.000 & 10.000 \\
Democracy, UDS Mean Score & 0.004 & 0.979 & -2.112 & 2.263 \\
Democracy, Vanhanen & 8.995 & 11.765 & 0.000 & 47.080 \\
Democracy, Boix & 0.364 & 0.481 & 0.000 & 1.000 \\
Executive Electoral Competitiveness, DPI & 5.209 & 2.154 & 1.000 & 7.000 \\
Freedom of Speech, EQIO & 2.212 & 0.681 & 1.000 & 3.000 \\
Freedom of Association, EQIO & 2.406 & 0.717 & 1.000 & 3.000 \\
Media Freedom, Whitten-Woodring and & 0.741 & 0.846 & 0.000 & 2.000 \\
Van Belle & & & & \\
Oversight Powers, CCP & 2.569 & 1.230 & 1.000 & 4.000 \\
Checks and Balances, Beck et al. & 2.525 & 1.703 & 1.000 & 18.000 \\
\hline Number of Observations & 18655 & & & \\
\hline
\end{tabular}


Figure 1. Diagram of Control Variables

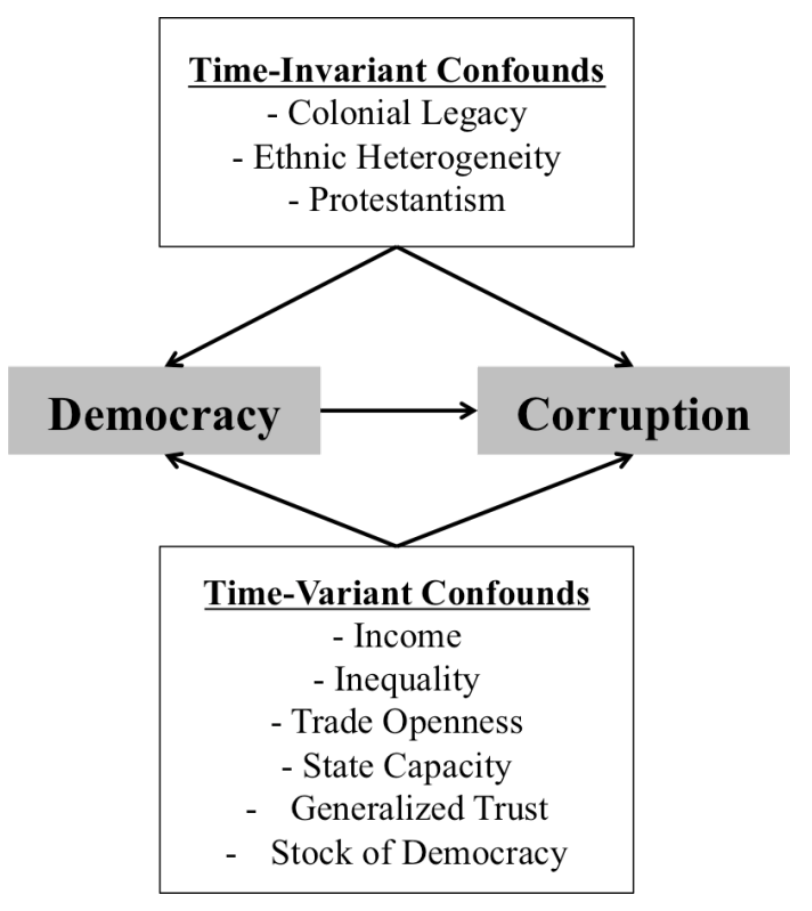


Table 2. Controls (next page)

This table considers the same models we present in the paper, adding the four control variables we discuss in the paper but do not include in our main analyses: state capacity, GDP per capita, trade openness, GINI coefficient. Model 1 here is Model 4 from Table 1 in the paper with the control variables included. Model 2 here is that same model run without the control variables but on the same sample as in Model 1, showing that the loss of statistical significance is driven by the loss in observations, not by the introduction of control variables. The remaining models replicate the sequence of models in Tables 2-4 in the paper, with control variables included. 


\begin{tabular}{|c|c|c|c|c|c|c|c|c|}
\hline & (1) & $(2)$ & (3) & (4) & (5) & (6) & $(7)$ & (8) \\
\hline \multirow[t]{2}{*}{ Comuption Index, Lagged (1 Year) } & $1.0195^{212}$ & $1.0233^{2 n}$ & $1.0178^{2+12}$ & $1.0171^{\mu+1}$ & $1.0179^{m+12}$ & $1.0159^{2+1}$ & $1.0271^{\pi+1}$ & $1.0195^{2 m}$ \\
\hline & $(0.0215)$ & $(0.0219)$ & $(0.0204)$ & $(0.0199)$ & $(0.0219)$ & $(0.0219)$ & $(0.0213)$ & $(0.0218)$ \\
\hline \multirow[t]{2}{*}{ Comuption Index, Lagged (2 Years) } & $-0.0988^{*+*}$ & $-0.0972^{\cdots}$ & $-0.0968^{* *-6}$ & $-0.0957^{* *}$ & $-0.0982^{* \ldots}$ & $-0.0987^{* \ldots}$ & $-0.0978^{* * *}$ & $-0.1003^{+* *}$ \\
\hline & $(0.0197)$ & $(0.0198)$ & $(0.0193)$ & $(0.0190)$ & $(0.0197)$ & $(0.0193)$ & $(0.0198)$ & $(0.0200)$ \\
\hline \multirow{2}{*}{$\begin{array}{l}\text { Electoral Democracy, Lagged } \\
\text { (1 Year) }\end{array}$} & 0.0002 & 0.0081 & & & 0.0015 & 0.0141 & & \\
\hline & $(0.0204)$ & $(0.0191)$ & & & $(0.0223)$ & $(0.0206)$ & & \\
\hline \multirow[t]{2}{*}{ Electoral Democracy ${ }^{\wedge}$} & -0.0243 & -0.0262 & & & -0.0186 & -0.0218 & & \\
\hline & $(0.0238)$ & $(0.0215)$ & & & $(0.0229)$ & $(0.0226)$ & & \\
\hline \multirow{2}{*}{$\begin{array}{l}\text { Freedom of Expression, Lagged (1 } \\
\text { Year) } \\
\text { Freedom of Expression }{ }^{\wedge} 2\end{array}$} & & & 0.0237 & & & & & \\
\hline & & & $\begin{array}{c}-0.0352^{*} \\
(0.0188)\end{array}$ & & & & & \\
\hline \multirow{4}{*}{$\begin{array}{l}\text { Freedom of Association, Lagged (1 } \\
\text { Year) } \\
\text { Freedom of Association }{ }^{\wedge} 2\end{array}$} & & & & 0.0299 & & & & \\
\hline & & & & $(0.0195)$ & & & & \\
\hline & & & & $-0.0420^{\circ}$ & & & & \\
\hline & & & & $(0.0193)$ & & & & \\
\hline $\begin{array}{l}\text { Judicial Constraints on Executive, } \\
\text { Lagged (1 Year) }\end{array}$ & & & & & $\begin{array}{l}-0.0042 \\
(0.0089)\end{array}$ & & & \\
\hline $\begin{array}{l}\text { Legislative Constraints on } \\
\text { Executive, Lagged (1 Year) }\end{array}$ & & & & & & $\begin{array}{l}-0.0175^{* * *} \\
(0.0058)\end{array}$ & & \\
\hline Electoral Regime, Lagged (1 Year) & & & & & & & $\begin{array}{l}-0.0028 \\
(0.0021)\end{array}$ & $\begin{array}{c}0.0022 \\
(0.0028)\end{array}$ \\
\hline $\begin{array}{l}\text { Reduced F\&F Elections Index, } \\
\text { Lagged (1 Year) }\end{array}$ & & & & & & & & $\begin{array}{l}-0.0168 * \\
(0.0075)\end{array}$ \\
\hline Stock of Democracy, Lagged (1 & $0.0020^{* *}$ & $0.0019^{* *}$ & $0.0017^{* *}$ & $0.0020^{\circ-}$ & $0.0021^{* *}$ & $0.0024^{* * *}$ & 0.0004 & $0.0016^{\circ}$ \\
\hline \multirow{3}{*}{$\begin{array}{l}\text { Year) } \\
\text { GDP Per Capita, Lagged (1 Year) }\end{array}$} & $(0.0008)$ & $(0.0008)$ & $(0.0008)$ & $(0.0008)$ & $(0.0008)$ & $(0.0008)$ & $(0.0008)$ & $(0.0009)$ \\
\hline & -0.0009 & & -0.0002 & -0.0003 & -0.0001 & -0.0001 & -0.0001 & -0.0002 \\
\hline & $(0.0013)$ & & $(0.0003)$ & $(0.0003)$ & $(0.0003)$ & $(0.0003)$ & $(0.0003)$ & $(0.0003)$ \\
\hline \multirow{2}{*}{$\begin{array}{l}\text { GDP Per Capita x Electoral } \\
\text { Democracy }\end{array}$} & 0.0009 & & & & & & & \\
\hline & $(0.0014)$ & & & & & & & \\
\hline \multirow[t]{2}{*}{ Trade Openness, Lagged (1 Year) } & $-0.0046^{+1 .}$ & & $-0.0044^{* *}$ & $-0.0043^{* *}$ & $-0.0044^{* *}$ & $-0.0043^{*+*}$ & $-0.0045^{* * *}$ & $-0.0045^{+4 t}$ \\
\hline & $(0.0011)$ & & $(0.0011)$ & $(0.0011)$ & $(0.0011)$ & $(0.0011)$ & $(0.0011)$ & $(0.0011)$ \\
\hline \multirow[t]{2}{*}{ Gini Coefficient, Lagged (1 Year) } & -0.0000 & & -0.0000 & -0.0001 & -0.0000 & 0.0000 & -0.0001 & -0.0000 \\
\hline & $(0.0001)$ & & $(0.0001)$ & $(0.0001)$ & $(0.0001)$ & $(0.0001)$ & $(0.0001)$ & $(0.0001)$ \\
\hline \multirow[t]{2}{*}{ State Capacity, Lagged (1 Year) } & $-0.0039^{\circ}$ & & $-0.0041^{*}$ & -0.0039 & $-0.0042^{*}$ & $-0.0046^{\circ}$ & -0.0039 & $-0.0040^{\circ}$ \\
\hline & $(0.0023)$ & & $(0.0024)$ & $(0.0024)$ & $(0.0023)$ & $(0.0024)$ & $(0.0023)$ & $(0.0023)$ \\
\hline$R^{2}$ & 0.8897 & 0.8893 & 0.8897 & 0.8398 & 0.8897 & 0.8901 & 0.8894 & 0.8897 \\
\hline No. Obsenvations & 4551 & 4551 & 4551 & 4551 & 4551 & 4549 & 4551 & 4550 \\
\hline
\end{tabular}




\section{Table 3. Outliers}

Model 1 here is Model 4 in Table 1 in the paper. From this, we identified the points with high leverage and high squared residuals. This revealed five outliers: Vietnam in 1914, Tunisia in 2011, Georgia in 2004, Palestine in 2006, Palestine in 2007. To be conservative, we removed those in Model 2. The results are relatively unchanged.

\begin{tabular}{lll}
\hline & $(1)$ & $(2)$ \\
& Corruption Index & Corruption Index \\
\hline Corruption Index, Lagged (1 Year) & $1.0366^{* * *}$ & $1.0393^{* * *}$ \\
& $(0.0100)$ & $(0.0097)$ \\
Corruption Index, Lagged (2 Years) & $-0.0810^{* * *}$ & $-0.0824^{* * *}$ \\
& $(0.0100)$ & $(0.0096)$ \\
Electoral Democracy, Lagged (1 Year) & $0.0147^{* *}$ & $0.0140^{* *}$ \\
Year) & $(0.0072)$ & $(0.0070)$ \\
Electoral Democracy^2 & $-0.0275^{* * *}$ & $-0.0264^{* * *}$ \\
Years & $(0.0085)$ & $(0.0082)$ \\
Stock of Democracy, Lagged (1 Year) & $0.0016^{* * *}$ & $0.0015^{* * *}$ \\
& $(0.0005)$ & $(0.0005)$ \\
GDP Per Capita, Lagged (1 Year) & -0.0003 & -0.0003 \\
& $(0.0003)$ & $(0.0003)$ \\
GDP Per Capita x Electoral Democracy & 0.0002 & 0.0001 \\
& $(0.0003)$ & $(0.0003)$ \\
\hline$R^{2}$ & 0.9879 & 0.9887 \\
No. Observations & 10208 & 10203 \\
\hline Entries are regression coefficients, with standard errors clustered on countries, in parentheses. Country- and year-fixed \\
effects included in regressions but omitted from the table. \\
${ }^{*} p<0.10,{ }^{* *} p<0.05,{ }^{* * *} p<0.01$ & &
\end{tabular}


Table 4. Test of the S-curve with V-Dem Data

\begin{tabular}{ll}
\hline & $(1)$ \\
& Corruption Index \\
\hline Corruption Index, Lagged (1 Year) & $1.0361^{* * *}$ \\
& $(0.0169)$ \\
Corruption Index, Lagged (2 Years) & $-0.0809^{* * *}$ \\
& $(0.0160)$ \\
Corruption Index, Lagged (1 Year) & \\
Corruption Index, Lagged (2 Years) & \\
Electoral Democracy, Lagged (1 & \\
Year) & $0.0392^{* *}$ \\
Electoral Democracy^2 & $(0.0191)$ \\
& $-0.0949^{* *}$ \\
Electoral Democracy^3 & $(0.0475)$ \\
& 0.0511 \\
Stock of Democracy, Lagged (1 Year) & $(0.0349)$ \\
& $0.0016^{* * *}$ \\
GDP Per Capita, Lagged (1 Year) & $(0.0005)$ \\
& -0.0003 \\
GDP Per Capita x Electoral Democracy & $(0.0004)$ \\
& -0.0000 \\
$\mathrm{R}^{2}$ & $(0.0004)$ \\
No. Countries & 0.9324 \\
Avg. Years per Country & 154 \\
No. Observations & 66.3 \\
\hline
\end{tabular}

Entries are regression coefficients, with standard errors clustered on countries, in parentheses. Country- and yearfixed effects included in regressions but omitted from the table.

${ }^{*} p<0.10,{ }^{* *} p<0.05,{ }^{* * *} p<0.01$

\section{Table 5: Robustness Tests Using Non-V-Dem Data (next page)}

The table on the next page considers the same models we present in the paper, including non-VDem measures of the independent variables. Here, Freedom House and Polity Index, Democracy UDS Mean Score, Democracy Vanbanen, and Democracy Boix provide substitutes for the V-Dem Electoral Democracy index. EQIQ provides a substitute for the V-Dem Freedom of Expression and Freedom of Association measures. Checks and Balances, Beck et al. provides a substitute for V-Dem's Legislative Checks on Executive. Executive Electoral Competitiveness, DPI provides a substitute for the V-Dem Reduced Free and Fair Elections index. 


\begin{tabular}{|c|c|c|c|c|c|c|c|c|c|}
\hline & (1) & (2) & (3) & (4) & (5) & (6) & $(7)$ & (8) & (9) \\
\hline Comuption Index, Lagged (1 Year) & $\begin{array}{l}0.9931^{+12} \\
(0.0217)\end{array}$ & $\begin{array}{l}1.0210^{2-1} \\
(0.0191)\end{array}$ & $\begin{array}{l}1.0158^{2 \pi} \\
(0.0181)\end{array}$ & $1.0256^{212}$ & $1.0697^{+21}$ & $1.0651^{1+2}$ & $0.9974^{+21}$ & $1.0161^{+2}$ & $0.9984^{+12}$ \\
\hline Comuption Index, Lagged (2 & $-0.0771^{\ldots}$ & $-0.0743^{\cdots}$ & $-0.0706^{* 1 .}$ & $-0.0740^{\circ}$ & $-0.2135^{*}$ & $-0.2126^{*}$ & $-0.0839^{*}$ & $-0.0651^{* \ldots}$ & $-0.0806^{*}$ \\
\hline Years) & $(0.0206)$ & $(0.0173)$ & $(0.0169)$ & $(0.0164)$ & $(0.0413)$ & $(0.0412)$ & $(0.0219)$ & $(0.0225)$ & $(0.0213)$ \\
\hline $\begin{array}{l}\text { Freedom House and Polity Index } \\
\text { Lagged (1 Year) }\end{array}$ & $\begin{array}{l}0.0045^{*} \\
(0.0017)\end{array}$ & & & & & & & & \\
\hline Freedom House and Polity Index 2 & $\begin{array}{l}-0.0004^{+1} \\
(0.0002)\end{array}$ & & & & & & & & \\
\hline $\begin{array}{l}\text { Democracy, UDS Mean Score, } \\
\text { Lagged (1 Year) } \\
\text { Democracy, UDS Mean Score`2 }\end{array}$ & & $\begin{array}{c}-0.0021 \\
(0.0013) \\
-0.0012 \\
(0.0006)\end{array}$ & & & & & & & \\
\hline $\begin{array}{l}\text { Democracy, Vanhanen, Lagged } \\
\text { (1 Year) } \\
\text { Democracy, Vanhanen`2 }\end{array}$ & & & $\begin{array}{l}-0.0001 \\
(0.0002) \\
-0.0000\end{array}$ & & & & & & \\
\hline & & & $(0.0000)$ & & & & & & \\
\hline Democracy, Boix, Lagged (1 Year) & & & & $\begin{array}{l}-0.0024^{* *} \\
(0.0011)\end{array}$ & & & & & \\
\hline $\begin{array}{l}\text { Freedom of Speech, EQIO, Lagged } \\
\text { (1 Year) }\end{array}$ & & & & & $\begin{array}{l}-0.0082 \\
(0.0148)\end{array}$ & & & & \\
\hline Freedom of Speech, EQIO 2 & & & & & $\begin{array}{c}0.0026 \\
(0.0035)\end{array}$ & & & & \\
\hline $\begin{array}{l}\text { Freedom of Association, EQIO, } \\
\text { Lagged (1 Year) }\end{array}$ & & & & & & $\begin{array}{c}0.0122 \\
(0.0183)\end{array}$ & & & \\
\hline Freedom of Association, EQIO ${ }^{\prime} 2$ & & & & & & $\begin{array}{l}-0.0020 \\
(0.0043)\end{array}$ & & & \\
\hline $\begin{array}{l}\text { Checks and Balances, Beck et al, } \\
\text { Lagged (1 Year) }\end{array}$ & & & & & & & $\begin{array}{l}-0.0005 \\
(0.0004)\end{array}$ & & \\
\hline Oversight Powers, CCP & & & & & & & & $\begin{array}{c}0.0005 \\
(0.0006)\end{array}$ & \\
\hline $\begin{array}{l}\text { Executive Electoral Competitiveness } \\
\text { DPI, Lagged (1 Year) }\end{array}$ & & & & & & & & & $\begin{array}{l}-0.0011^{*-} \\
(0.0005)\end{array}$ \\
\hline $\begin{array}{l}\text { Stock of Democracy, Lagged (1 } \\
\text { Year) }\end{array}$ & $\begin{array}{c}0.0010 \\
(0.0011) \\
\end{array}$ & $\begin{array}{r}0.0006 \\
(0.0000) \\
\end{array}$ & $\begin{array}{r}0.0010^{*} \\
(0.0005) \\
\end{array}$ & $\begin{array}{c}0.0005 \\
(0.0004) \\
\end{array}$ & $\begin{array}{c}0.0002 \\
(0.0023) \\
\end{array}$ & $\begin{array}{l}-0.0003 \\
(0.0022) \\
\end{array}$ & $\begin{array}{c}0.0011 \\
(0.0008) \\
\end{array}$ & $\begin{array}{l}0.0011^{* *} \\
(0.0005)\end{array}$ & $\begin{array}{c}0.0013 \\
(0.0008)\end{array}$ \\
\hline$\overline{R^{2}}$ & 0.8750 & 0.9117 & 0.9051 & 0.9168 & 0.8166 & 0.8167 & 0.8685 & 0.9177 & 0.8702 \\
\hline No. Countries & 157 & 168 & 165 & 159 & 156 & 156 & 164 & 165 & 164 \\
\hline $\begin{array}{l}\text { Avg. Years per Country } \\
\text { No. Observations }\end{array}$ & $\begin{array}{l}36.2 \\
5650\end{array}$ & $\begin{array}{l}51.2 \\
8602\end{array}$ & $\begin{array}{l}56.3 \\
9288\end{array}$ & $\begin{array}{l}63.1 \\
10030\end{array}$ & $\begin{array}{l}6.7 \\
1051\end{array}$ & $\begin{array}{l}6.7 \\
1051\end{array}$ & $\begin{array}{l}33.4 \\
5475\end{array}$ & $\begin{array}{l}54.2 \\
8941\end{array}$ & $\begin{array}{l}34.2 \\
5615\end{array}$ \\
\hline
\end{tabular}




\section{List of Variables Appearing in Table 5:}

Freedom House and Polity Index: To create this index the average of Freedom House's two scores are taken and are transformed to a scale 0-10 and Polity is transformed to a scale 0-10, and then these are averaged. The scale for this index ranges from 0 to 10 where 0 is least democratic and 10 most democratic. Source: Freedom House (e_fh_polity2)

Democracy, UDS Mean Score: The UDS are estimated using a Bayesian statistical measurement model and, therefore, can be used to make probabilistic statements about other useful quantities, such as the difference in democracy levels between two countries in a given year. The mean forming this measure is the posterior mean. Source: Pemstein et al. (2010) (e_uds_mean)

Democracy, Vanhanen: This variable is created by multiplying Vanhanen's Competition and Participation scores and dividing the resulting product by 100. Vanhanen's Competition score measures opposition party vote shares. Vanhanen's Participation score measures the percentage of population participating in elections. The resulting democracy scale varies from 0 to 50 . Source: Vanhanen 2000 (e_mivanhan).

Democracy, Boix: This variable provides a dichotomous measure of democracy based on contestation and participation. Contestation is determined by whether political leaders are selected through free and fair elections. Participation is determined by a minimum level of suffrage. Values are coded as 1 for a democracy and 0 for a non-democracy. Source: Boix, Miller, and Rosato 2013 (e_boix_regime)

Oversight Powers, CCP: This variable provides an ordinal measure for executive oversight by the legislature. The main responses include: (1) the legislature can call on the executive to report as it sees fit; (2) the executive must report to the legislature at regular intervals; (3) both; and (4) neither. Source: Elkins et al. 2012 (e_ccp_intexec)

Executive Electoral Competitiveness, DPI: This variable provides a dichotomous scale that measures if the executive is elected directly (1) or through an electoral college (2). Source: Beck et al. 2001 (e_dpi_eipc)

Freedom of Association, EQIO: This variable provides an ordinal scale with three possible values: (1) citizens do not have freedom of association, (2) freedom of association exists with some problems, (3) citizens have freedom of association,. Source: Kelley and Kolev 2010 (e_SF2)

Freedom of Speech, EQIO: This variable provides an ordinal scale with three possible values: (1) citizens do not have freedom of speech, (2) freedom of speech exists with some problems, or (3) citizens have freedom of speech. Source: Kelley and Kolev 2010 (e_SF3)

Checks and Balances, Beck et al.: This variable provides a measure for the number of veto players in the government, adjusted for the level of independence of each branch, party affiliation, and electoral rules. The scale ranges from 0 to 18. Source: Beck et al. (2001) (e_dpi_checks)

Note: Names of variables as they appear in the V-Dem dataset are given at the end of each entry. 
References for List of Variables Appearing in Table 5: Beck, Thorsten, George Clarke, Alberto Groff, Philip Keefer and Patrick Walsh. 2001. "New Tools in Comparative Political Economy: The Database of Political Institutions." World Bank Economic Review 15, no. 1: 165-176. Boix, Carles, Michael Miller and Sebastian Rosato. 2013. "A Complete Data Set of Political Regimes, 1800-2007." Comparative Political Studies 46, no. 12: 1523-1554. Coppedge, Michael, John Gerring, Staffan I. Lindberg, Svend-Erik Skaaning, Jan Teorell, David Altman, Michael Bernhard, M. Steven Fish, Adam Glynn, Allen Hicken, Carl Henrik Knutsen, Kelly McMann, Pamela Paxton, Daniel Pemstein, Jeffrey Staton, Brigitte Zimmerman, Frida Andersson, Valeriya Mechkova and Farhad Miri. 2016. "V-Dem Codebook V6.2." Elkins, Zachary, Tom Ginsburg, James Melton. 2012. Comparative Constitutions Project (CCP). URL: www.comparativeconstitutionsproject.org/ Kelley, Judith G and Kiril Kolev. 2010. "Election Quality and International Observation 1975-2004: Two New Datasets." Pemstein, Daniel, Stephen A Meserve and James Melton. 2010. "Democratic Compromise: A Latent Variable Analysis of Ten Measures of Regime Type." Political Analysis 18, no. 4: 426-449. Vanhanen, Tatu. 2000. "A New Dataset for Measuring Democracy, 1810-1998." Journal of Peace Research 37, no. 2: $251-265$.

\section{Robustness Tests Using Non-Overlapping Coders (Table 6)}

As noted in the text, we attempt to correct for a potential endogeneity bias by leveraging in the V-Dem data the fact that, in most countries, different country-experts responded to different "surveys", i.e. thematically grouped sets of questions. To the extent that the indicators tapping into corruption appear in other such surveys than the indicators tapping into the constructs measuring our six hypotheses, we can accordingly eliminate country experts responding to questions on both sides of the equation. Four of the corruption indicators appear in the executive survey, one in the legislative and one in the judicial survey, whereas all freedom of expression, freedom of association and clean elections indicators appear in distinct surveys (on elections, parties, civil society, civil liberties and the media). When testing the effects of judicial and legislative constraints, we accordingly construct a measure of corruption without the indicator from these surveys, respectively. Table 5 below then replicates the results in Tables 2-4 in the text, with one model per hypothesis (except the fifth model which tests H5 and H6 simultaneously), but on data where country experts appearing on both sides of the equation are being excluded.

It should be noted however that these analyses preclude drawing on estimates from the V-Dem measurement model, which of course relies on data from all country experts responding to any indicator. We are instead forced to rely on simple averaging as the method of aggregating scores across country experts. No account is thus taken to potentially varying thresholds or lateral coding. With this caveat in mind, the results are fairly straight-forward. The most robust effects appear to be the ones for freedom of association (still significantly curvilinear) and free 
and fair elections (still significantly positive for holding elections, significantly linearly negative for freedom and fairness). The squared term for freedom of expression is only marginally significant, and the additive term is not significant, so freedom of expression, when excluding coders appearing on both sides, mostly reduces corruption in a monotonically decreasing fashion. There is no significant result for judicial constraints, and a marginally significant but positive effect of legislative constraints (counter to the hypothesis). So, overall, when taking the precaution of excluding coders appearing on both sides of the equation, we find strongest support for H2, H5 and H6. .

Table 6: Robustness Tests Using Non-Overlapping Coders

\begin{tabular}{|c|c|c|c|c|c|}
\hline & $\begin{array}{l}\text { (1) } \\
\text { Testing } \\
\text { H1 }\end{array}$ & $\begin{array}{l}\text { (2) } \\
\text { Testing } \\
\text { H2 }\end{array}$ & $\begin{array}{l}\text { (3) } \\
\text { Testing } \\
\text { H3 }\end{array}$ & $\begin{array}{l}\text { (4) } \\
\text { Testing } \\
\text { H4 }\end{array}$ & $\begin{array}{l}\text { (5) } \\
\text { Testing } \\
\text { H5-H6 }\end{array}$ \\
\hline $\begin{array}{l}\text { Corruption Index, Lagged } \\
\text { (1 Year) }\end{array}$ & $\begin{array}{l}.9454^{* * *} \\
(.0400)\end{array}$ & $\begin{array}{l}.5589^{* * *} \\
(.0340)\end{array}$ & $\begin{array}{l}.9734^{* * *} \\
(.0196)\end{array}$ & $\begin{array}{l}.9795^{* * *} \\
(.0278)\end{array}$ & $\begin{array}{l}.6041^{* * *} \\
(.0212)\end{array}$ \\
\hline $\begin{array}{l}\text { Corruption Index, Lagged } \\
\text { (2 Year) }\end{array}$ & $\begin{array}{l}.0202 \\
(.0390)\end{array}$ & $\begin{array}{l}.3822^{* * *} \\
(.0324)\end{array}$ & $\begin{array}{l}-.0117 \\
(.0199)\end{array}$ & $\begin{array}{l}-.0377 \\
(.0227)\end{array}$ & $\begin{array}{l}.3267^{* * *} \\
(.0185)\end{array}$ \\
\hline $\begin{array}{l}\text { Freedom of Expression, Lagged } \\
\quad(1 \text { Year }) \\
\text { Freedom of Expression^2 }\end{array}$ & $\begin{array}{l}.0212 \\
(.0135) \\
-.0224^{*} \\
(.0131)\end{array}$ & & & & \\
\hline $\begin{array}{l}\text { Freedom of Association, Lagged } \\
\text { (1 Year) }\end{array}$ & & $\begin{array}{l}.0487^{* * *} \\
(.0115)\end{array}$ & & & \\
\hline Freedom of Association^2 & & $\begin{array}{l}-.0494^{* * *} \\
(.0125)\end{array}$ & & & \\
\hline $\begin{array}{l}\text { Judicial Constraints on } \\
\text { Executive, Lagged (1 Year) }\end{array}$ & & & $\begin{array}{l}-.0020 \\
(.0038)\end{array}$ & & \\
\hline $\begin{array}{l}\text { Legislative Constraints on } \\
\text { Executive, Lagged (1 Year) }\end{array}$ & & & & $\begin{array}{l}.0160^{*} \\
(.0081)\end{array}$ & \\
\hline $\begin{array}{l}\text { Electoral Regime, Lagged } \\
\quad(1 \text { Year) }\end{array}$ & & & & & $\begin{array}{l}.0089^{* * *} \\
(.0024)\end{array}$ \\
\hline $\begin{array}{l}\text { Reduced F\&F Elections, } \\
\text { Lagged (1 Year) }\end{array}$ & & & & & $\begin{array}{l}-.0206^{* * *} \\
(.0044)\end{array}$ \\
\hline$R^{2}$ & 0.9256 & 0.8435 & 0.9308 & 0.8911 & 0.8386 \\
\hline No. Countries & 132 & 169 & 169 & 89 & 169 \\
\hline Avg. Years Per Country & 59.5 & 83.2 & 83.0 & 43.1 & 76.8 \\
\hline No. Observations & 7859 & 14068 & 14032 & 3834 & 12983 \\
\hline
\end{tabular}

